\title{
Isolation and Evaluation of Cellulolytic Yeasts for Production of Ethanol from Wheat Straw
}

\author{
Geeta Shirnalli, M. Ashwini* and Dhanashree Gachhi \\ AICRP ON EAAI (Bioconversion Technology), Main Agriculture Research Station, \\ University of Agricultural Sciences, Dharwad-580 005, Karnataka, India \\ *Corresponding author
}

\begin{tabular}{|c|c|}
\hline & A B S T R A C T \\
\hline $\begin{array}{l}\text { Cellulolytic yeasts, } \\
\text { Fruit wastes, } \\
\text { Ethanol, } \\
\text { Saccharification, } \\
\text { Lignocellulosic } \\
\text { waste }\end{array}$ & \multirow{3}{*}{$\begin{array}{l}\text { The cellulolytic efficiency of yeast isolates obtained from different fruit and fruit wastes } \\
\text { was evaluated in terms of degradation of cellulose, release of reducing sugars and } \\
\text { bioethanol production. The isolates CY-3, CY-4, CY- } 8 \text { and CY-15 together with a } \\
\text { reference cellulolytic strain Saccharomyces cerevisiae (NCIM 3220) displayed maximum } \\
\text { hydrolysis of carboxy methyl cellulose (CMC) to yield reducing sugars when determined } \\
\text { in } 2 \text { days interval for up to } 22 \text { days, Based on this, the isolates were further evaluated for } \\
\text { combined saccharification and fermentation of a pretreated lignocellulosic substrate such } \\
\text { as wheat straw in flask culture studies. The concentration of ethanol produced by the } \\
\text { cellulolytic yeasts at the end of fermentation was determined by Gas Chromatography. } \\
\text { Strain CY- } 15 \text { produced } 0.573 \mathrm{~g} / \mathrm{L} \text { of ethanol which was on par with the reference strain } \\
\text { which produced } 0.68 \mathrm{~g} / \mathrm{L} \text {. Thus the study attempts to develop a sustainable bioethanol } \\
\text { production technology by simultaneous saccharification and fermentation of wheat straw } \\
\text { using native yeasts. }\end{array}$} \\
\hline Article Info & \\
\hline $\begin{array}{l}\text { Accepted: } \\
\text { 17 November } 2018 \\
\text { Available Online: } \\
10 \text { December } 2018\end{array}$ & \\
\hline
\end{tabular}

\section{Introduction}

Production of ethanol from lignocellulosic biomass seems very attractive and sustainable due to several reasons, among which the renewable and ubiquitous nature of biomass and its non competitiveness with food crops are the major ones. The utilization of lignocellulosic biomass for ethanol production necessitates the large-scale production technology to be cost effective and environmentally sustainable. Extensive research has been targeted in the last decade to come out with a self sufficient process to convert the lignocellulosic biomass to bioethanol so as to meet the increasing bioenergy demands. However the development of a single bioprocess combining cellulase production, saccharification, and fermentation into one step has still remained a challenge (Ask et al., 2012). This consolidated bioprocessing (CBP) has been proposed as the most efficient way to reduce the production cost of cellulosic bioethanol (Kang et al., 2015). 
Several raw materials are being used for the bioethanol production viz. easily fermentable sugary feed stocks (molasses), starchy feed stocks (grains) and feed stocks containing complex sugars in the form of cellulose and hemicelluloses (Li et al., 2009; Choi et al., 2010; Zhao and Xia, 2010). The hydrolysis of cellulose and hemicelluloses polysaccharides into their respective monomers called as saccharification involves cellulolytic microorganisms or their enzymes namely cellulase and hemicellulase (Erdei et al., 2012 and $\mathrm{Lu}$ et al., 2013). Yeast strains are known for fermentation of sugars to yield ethanol. Since lignocellulosic substrates contain pentoses as well as hexoses, only few types of yeast are known to utilize it. If the yeast can do the process of hydrolysis as well as fermentation, then the cost of hydrolytic enzymes can be avoided.

Thus the current work deals with isolation of native yeasts with saccharolytic and fermentative abilities for application in bioethanol production from lignocellulosic waste wheat straw.

\section{Materials and Methods}

\section{Pure cultures and growth medium}

Yeasts were isolated from different sources such as fruits and fruit wastes (Table 1). The isolates were purified, subcultured and maintained on MGYP Agar (Malt Extract Glucose Yeast Extract Peptone) medium. A reference strain of yeast Saccharomyces cerevisiae (NCIM 3220) with cellulolytic ability was procured from National Collection of Industrial Microorganisms (NCIM), Pune.

Screening of the yeasts for cellulolytic ability

All the yeast isolates were subjected to test for saccharification of carboxy methyl cellulose
(CMC). The amount of reducing sugars liberated was estimated by dinitrosalicylic acid (DNSA) method (Miller et al., 1960). Carboxymethyl cellulose (CMC) of $0.50 \mathrm{~g}$ was dissolved in $49.50 \mathrm{ml}$ of sodium citrate buffer $(0.50 \mathrm{M}, \mathrm{pH} 4.8)$ by vigorous stirring until the CMC was completely dissolved. This solution had the cellulose concentration of one $\mathrm{mg}$ per $\mathrm{ml}$. To $0.80 \mathrm{ml}$ of CMC solution (1 $\mathrm{mg}$ $\mathrm{ml}^{-1}$ ) $0.80 \mathrm{ml}$ of appropriately diluted culture supernatant was added. The reaction system was incubated for $10 \mathrm{~min}$ at $50{ }^{\circ} \mathrm{C}$. After the incubation, the volume was made up to $3 \mathrm{ml}$ using distilled water. $3 \mathrm{ml}$ of DNSA reagent was added to each sample, mixed well. The reagent blank containing $3 \mathrm{ml}$ of distilled water and $3 \mathrm{ml}$ of DNSA reagent was also prepared. Similarly, standards were also included whose glucose concentration ranged from $10 \mu \mathrm{g}$ to $100 \mu \mathrm{g}$. All tubes viz., samples, standards and blank were kept on boiling water bath for 5 minutes. After this one $\mathrm{ml}$ of 40 per cent Rochelle salt solution was added when the reaction mixture was still warm. Then the tubes were cooled. The absorbance in terms of optical density of the standards and sample were read at $510 \mathrm{~nm}$ using Systronics UV Spectrophotometer-117.

\section{Saccharification and fermentation of wheat straw by the yeasts}

To determine the period for maximum saccharification, the following experiment was undertaken. Wheat straw was pretreated by the method standardised earlier in our laboratory using $3 \% \mathrm{NaOH}$ for $8 \mathrm{~h}$. About $5 \mathrm{~g}$ each of oven dried substrates was sterilized in an autoclave in $250 \mathrm{ml}$ Earlen Mayer flask. To this $100 \mathrm{ml}$ of sterile distilled water was added to get $5 \%$ substrate concentration. The $\mathrm{pH}$ was adjusted to 5.5. Fresh cultures of cellulolytic yeast isolates were inoculated at the rate of $2 \%$. To this nutrients consisting of Urea $0.64 \%, \mathrm{KH}_{2} \mathrm{PO}_{4}$ at $0.2 \%$ and $\mathrm{MgSO}_{4}$ at $0.1 \%$ concentration was added. The flasks were kept 
under aerobic condition and reducing sugar was analyzed at $24 \mathrm{~h}$ intervals. The flasks were incubated for 5 days under aerobic condition followed by creating an anaerobic condition for about 7 days or till the carbon dioxide evolution ceased. Later the residual reducing sugar and ethanol produced was analysed.

\section{Analysis of ethanol using gas chromatography}

The ethanol obtained after fermentation of Wheat straw using cellulolytic yeast isolates was analysed using GC (Table 2). For sample preparation, $2 \mathrm{ml}$ of the supernatant from the individual treatments at end of fermentation was centrifuged at $10,000 \mathrm{rpm}$ for $10 \mathrm{~min}$. Ethanol standard as well as the samples were filtered through syringe driven filter nylon 66 of $0.22 \mu$ pore size and stored frozen until use.

The GC used in this study was an Agilant 7260, USA with a flame ionization detector. Separation took place in $2 \mathrm{~m} \mathrm{DB}$ wax column using nitrogen as the carrier gas. The $\mathrm{GC}$ oven temperature was initially controlled at $65{ }^{\circ} \mathrm{C}$ for $5 \mathrm{~min}$, and then it was increased at a rate of $40{ }^{\circ} \mathrm{C}$ per min to a final temperature of $140{ }^{\circ} \mathrm{C}$, which was held for $3 \mathrm{~min}$. The temperature of the injector was set at $240{ }^{\circ} \mathrm{C}$ and the detector was set at $250{ }^{0} \mathrm{C}$ with $\mathrm{H}_{2}$ flow at $25 \mathrm{ml} / \mathrm{min}$, air $100 \mathrm{ml} / \mathrm{min}$ and $\mathrm{N}_{2}$ at $25 \mathrm{ml} / \mathrm{min}$. The injection volume was $0.1 \mu \mathrm{l}$ with split mode of ratio 65:1. Data acquisition software was used to integrate the data.

\section{Results and Discussion}

Our study emphasizes on the dire need to isolate and explore potential native yeasts with natural cellulolytic and fermentative abilities. In the present study, fruit and fruit wastes were used as source of cellulolytic yeasts. Fruit and fruit wastes are a natural source of mono and disachharides for yeast growth. A total of twenty yeasts were isolated from different fruit and fruit wastes as shown in table 1 . The ability of the isolates to convert carboxy methyl cellulose to yield reducing sugars was tested in order to determine their saccharification potential. Several yeast species have been isolated from different fruits, fruit juices and wastes with ability to produce extracellular enzymes and ethanol production (Rao et al., 2008, Chatterjee et al., 2011 and Zahida et al., 2014). Bioconversion of lignocellulosic sugar into ethanol by genetically engineered cellulolytic yeasts has been investigated by a number of researchers (Kuhad et al., 2011). Fujita et al., (2003) studied the synergistic saccharification and direct fermentation to ethanol of amorphous cellulose by engineered yeast strain displaying all three types of cellulolytic enzymes. However, wild yeasts from different natural substrates possess innate saccharification and ethanol producing capabilities.

In our study, isolates CY-3, CY-4, CY-8 and CY-15 displayed maximum hydrolysis of CMC to yield reducing sugars when determined in a 2 day interval for up to 22 days. Isolate CY-4 from the pulp of sweet lemon yielded a maximum of $550.66 \mathrm{mg}$ of reducing sugars/gm of CMC on the $22^{\text {nd }}$ day. Based on this, the isolates were further evaluated for combined saccharification and fermentation of a lignocellulosic waste such as wheat straw in flask culture studies. A reference strain of Saccharomyces cerevisiae with cellulolytic ability was included in the study.

When using lignocellulosic waste as substrate for bioethanol production, pretreatment becomes necessary by either physical or chemical methods to make the substrate accessible for further enzymatic saccharification (Srichuwong et al., 2009 and Koo et al., 2011). It can have significant effect on both saccharification and production of ethanol. It also influences the amount of ethanol yield and production cost (Koo et al., 2011). 
Table.1 Cellulolytic activity of the yeast isolates in terms of release of reducing sugars (mg g-1 of CMC)

\begin{tabular}{|c|c|c|c|c|c|c|c|c|c|c|c|c|}
\hline \multirow{3}{*}{$\begin{array}{l}\text { Sl. } \\
\text { No }\end{array}$} & \multirow{3}{*}{$\begin{array}{l}\text { Isolate no. and } \\
\text { Source of isolation }\end{array}$} & \multicolumn{11}{|c|}{ Reducing sugars mg g ${ }^{-1}$ Carboxy Methyl Cellulose } \\
\hline & & \multicolumn{11}{|c|}{ Period of Incubation (Days) } \\
\hline & & 2 & 4 & 6 & 8 & 10 & 12 & 14 & 16 & 18 & 20 & 22 \\
\hline 1 & $\begin{array}{l}\text { CY-1 } \\
\text { Straw berry }\end{array}$ & 0 & 0 & 0 & 66 & 107.33 & 125.33 & 161.0 & 180.33 & 234.0 & 261.66 & 278.33 \\
\hline 2 & $\begin{array}{l}\text { CY-2 } \\
\text { Straw berry }\end{array}$ & 2.0 & 3.66 & 16.33 & 25.33 & 28.33 & 52.10 & 110.66 & 194.0 & 304.66 & 326.66 & 460.33 \\
\hline 3 & $\begin{array}{l}\text { CY-3 } \\
\text { Sweet lemon skin }\end{array}$ & 0 & 0 & 4.0 & 10 & 64.0 & 208.66 & 271.0 & 275.66 & 313.66 & 428.66 & 463.33 \\
\hline 4 & $\begin{array}{l}\text { CY-4 } \\
\text { Pulp of sweet lemon }\end{array}$ & 16.33 & 24.66 & 80.66 & 201.33 & 285.0 & 322.33 & 398.0 & 443.33 & 475.66 & 509.0 & 550.66 \\
\hline 5 & $\begin{array}{l}\text { CY-5 } \\
\text { Papaya }\end{array}$ & 0 & 0 & 20.66 & 22.66 & 24.0 & 124.0 & 172.66 & 177.33 & 164.33 & 220.73 & 220.70 \\
\hline 6 & CY-6 fermented strawberry & 0 & 4.16 & 8.33 & 19.06 & 20.33 & 25.00 & 27.53 & 39.93 & 46.66 & 48.53 & 50.00 \\
\hline 7 & $\begin{array}{l}\text { CY-7 } \\
\text { Apple skin }\end{array}$ & 0 & 0 & 29.33 & 40.66 & 49.33 & 52.33 & 49.16 & 133.0 & 201.33 & 211.66 & 224.33 \\
\hline 8 & $\begin{array}{l}\text { CY-8 } \\
\text { Pulp of apple }\end{array}$ & 0 & 0 & 15.33 & 17.66 & 79.0 & 122.0 & 150.33 & 176.66 & 223.33 & 262.0 & 271.66 \\
\hline 9 & $\begin{array}{l}\text { CY-9 } \\
\text { Fermented silage }\end{array}$ & 0 & 0 & 4.093 & 19.66 & 21.93 & 22.86 & 28.30 & 32.26 & 38.66 & 41.90 & 55.80 \\
\hline 10 & $\begin{array}{l}\text { CY-10 } \\
\text { Fermented Laquot fruit }\end{array}$ & 0 & 3.00 & 6.90 & 17.33 & 23.76 & 24.60 & 25.36 & 29.13 & 49.20 & 68.66 & 76.76 \\
\hline 11 & $\begin{array}{l}\text { CY-11 } \\
\text { Skin of pomegranate }\end{array}$ & 0 & 0.166 & 0.833 & 3.833 & 8.20 & 15.20 & 15.60 & 18.06 & 23.06 & 39.03 & 48.46 \\
\hline 12 & $\begin{array}{l}\text { CY-12 } \\
\text { Pomegranate }\end{array}$ & 0 & 7.0 & 8.0 & 34.0 & 41.0 & 47.0 & 48.0 & 127.3 & 141.0 & 434.0 & 92.0 \\
\hline 13 & $\begin{array}{l}\text { CY-13 } \\
\text { Inner skin of pomegranate }\end{array}$ & 0 & 13.33 & 19.40 & 22.00 & 22.26 & 28.13 & 37.46 & 40.93 & 51.40 & 57.33 & 64.26 \\
\hline 14 & CY-14 & 0 & 22.10 & 22.60 & 38.80 & 41.20 & 41.76 & 49.43 & 57.16 & 61.36 & 64.16 & 66.46 \\
\hline
\end{tabular}


Int.J.Curr.Microbiol.App.Sci (2018) 7(12): 2215-2221

\begin{tabular}{|c|c|c|c|c|c|c|c|c|c|c|c|c|}
\hline & Inner skin of pomegranate & & & & & & & & & & & \\
\hline 15 & $\begin{array}{l}\text { CY-15 } \\
\text { Fermented juice of } \\
\text { pomegranate }\end{array}$ & 8.166 & 16.033 & 25.10 & 29.06 & 35.46 & 48.96 & 56.46 & 68.00 & 76.43 & 80.03 & 100.36 \\
\hline 16 & $\begin{array}{l}\text { CY-16 } \\
\text { Pomegranate fermented juice }\end{array}$ & 73.33 & 203.33 & 230.33 & 250.0 & 198.66 & 118.66 & 92.66 & 66.66 & 13.0 & 12.66 & 10.0 \\
\hline 17 & $\begin{array}{l}\text { CY-17 } \\
\text { Pulp of Apple }\end{array}$ & 0 & 13.06 & 18.83 & 26.20 & 35.26 & 46.43 & 52.13 & 68.10 & 71.33 & 88.36 & 89.00 \\
\hline 18 & $\begin{array}{l}\text { CY-18 } \\
\text { Skin of pomegranate }\end{array}$ & 6.00 & 11.16 & 19.36 & 22.83 & 49.00 & 55.03 & 61.43 & 78.26 & 80.03 & 90.03 & 126.20 \\
\hline 19 & $\begin{array}{l}\text { CY-19 } \\
\text { Inner skin of Baer fruit }\end{array}$ & 0 & 2.33 & 4.03 & 13.86 & 16.50 & 29.50 & 31.06 & 36.56 & 40.50 & 60.33 & 63.36 \\
\hline 20 & $\begin{array}{l}\text { CY-20 } \\
\text { Pulp of Baer fruit }\end{array}$ & 1.33 & 2.56 & 8.63 & 11.43 & 26.56 & 37.10 & 41.86 & 49.80 & 55.06 & 63.30 & 78.03 \\
\hline
\end{tabular}

Table.2 GC analysis of yeast isolates for ethanol production from wheat straw

\begin{tabular}{|c|c|c|c|}
\hline S1. No. & Strain Code & Retention time & Concentration of Ethanol (g/L) \\
\hline $\mathbf{1}$ & CY-3 & 3.9 & 0.236 \\
\hline $\mathbf{2}$ & CY-4 & 3.9 & 0.316 \\
\hline $\mathbf{3}$ & CY-8 & 4.0 & 0.350 \\
\hline $\mathbf{4}$ & CY-15 & 3.8 & 0.573 \\
\hline $\mathbf{5}$ & $\begin{array}{c}\text { Saccharomyces cerevisiae } \\
\text { (NCIM 3220) }\end{array}$ & 3.9 & $0.68 \mathrm{~g} / \mathrm{L}$ \\
\hline
\end{tabular}


Using yeasts to generate fuel ethanol has advantage of low distillation cost as it gives a high ethanol yield, a high productivity and can withstand high ethanol concentration (Kasavi et al., 2012). Particularly, S. cerevisiae is the most attractive yeast in industrial ethanol production as it tolerates a wide range of $\mathrm{pH}$ (Lin et al., 2012), thus reducing the contamination problem in the process. Yeast strains such as Pichia stipitis (NRRL-Y-7124), S. cerevisiae (RL-11) and Kluyveromyces fagilis (Kf1) were reported to produce good amount of ethanol from different types of sugars (Mussato et al., 2012).

In the present study, yeast CY-15 isolated from fermented juice of pomegranate showed maximum ethanol production amounting to $0.573 \mathrm{~g} / \mathrm{L}$ in flask culture studies using pretreated wheat straw. Mellitzer et al.,(2012) opined that, lignocellulolytic yeast such as of Pichia have simple media requirements and their relative easy handling in bioreactors enable inexpensive large-scale cultivations. Bioethanol production from biomass through enzymatic route has been investigated by several researchers with several amendments in the commercial preparation of cellulase for biomass hydrolysis, which contains higher and improved beta-glucosidase for efficient biomass conversion (Singhania et al., 2013).

From the results obtained and the discussion followed, it can be concluded that the characteristic features of yeasts in general and their possible cellulolytic enzymatic capabilities contribute to their high potential for cost reduction during the production of ethanol, thus obviating the need for expensive pure active lignocellulolytic enzymes. Optimization of factors which influence the production of bioethanol including temperature, sugar concentration, $\mathrm{pH}$, fermentation time, agitation rate, and inoculum size is warranted for the development of a successful and sustainable bioethanol production process.

\section{Acknowledgement}

This work was supported by grants from ICAR, All India Coordinated Research Project on EAAI (Bioconversion Technology).

\section{References}

Ask, M., Olofsson, K., Di Felice, T. et al., 2012. Challenges in enzymatic hydrolysis and fermentation of pretreated Arundo donax revealed by a comparison between SHF and SSF. Process Biochem. 47:14521459.

Chatterjee, S., Barnita Ghosh and Rina Rani Ray. 2011. Isolation and characterization of local yeast strains from waste fruit juices, jaggery and dahi samples. Int. J. Chem. Sci. 9(2):647-656.

Choi, G.W., Um, H.J., Kim, Y. et al., 2010. Isolation and characterization of two soil derived yeasts for bioethanol production on Cassava starch, Biomass- Bioenergy. 34: 1223-1231.

Erdei, B., B. Franko, M. Galbe and G. Zacchi. 2012. Separate hydrolysis and cofermentation for improved xylose utilization in integrated ethanol production from wheat meal and wheat straw, Biotechnol. Biofuels. 5: 1-12.

Fujita, Y., Junji Ito, Mitsuyoshi Ueda, Hideki Fukuda, Akihiko Kondo. 2004. Synergistic Saccharification, and Direct Fermentation to Ethanol, of Amorphous Cellulose by Use of an Engineered Yeast Strain Codisplaying Three Types of Cellulolytic Enzyme. Applied and Environmental Microbiology. 70(2):1207-1212.

Kang, K.E., Chung, D.-P., Kim, Y. et al., 2015. High-titer ethanol production from simultaneous saccharification and fermentation using a continuous feeding system. Fuel. 145: 18-24. 
Kasavi, C., I. Finore, L. Lama, et al., 2012. Evaluation of industrial Saccharomyces cerevisiae strains for ethanol production from biomass. Biomass- Bioenergy. 45:230-238.

Koo, B., H. Kim, N. Park, et al., 2011.Organosolv pretreatment of Liriodendron tulipifera and simultaneous saccharification and fermentation for bioethanol production. BiomassBioenergy. 35: 1833-1840.

Kuhad, R C., Rishi Gupta, Yogender PalKhasa, Ajay Singh Y.-H. Percival Zhang. 2011. Bioethanol production from pentose sugars: Current status and future prospects. Renewable and Sustainable Energy Reviews. 15(9): 4950-4962.

Li, H., N.J. Kim, M. Jiang, et al., 2009. Simultaneous saccharification and fermentation of lignocellulosic residues pretreated with phosphoric acid-acetone for bioethanol production, Bioresour. Technol. 100: 3245-3251

Lin, Y., W. Zhang, C. Li, et al., 2012.Factors affecting ethanol fermentation using Saccharomyces cerevisiae BY4742. Biomass- Bioenergy. 47: 395-401.

Lu, J., X. Li, R. Yang, et al., 2013. Fed-batch semi-simultaneous saccharification and fermentation of reed pretreated with liquid hot water for bio-ethanol production using Saccharomyces cerevisiae, Bioresour. Technol. 144: 539-547.

Mellitzer, A., Roland Weis, Anton Glieder and Karlheinz Flicker.2012. Expression of lignocellulolytic enzymes in Pichia pastoris. Microbial Cell Factories. 11:61.
Miller, G.L., Blum R, Glennon WE, Burton AL. 1960. Measurement of carboxymethylcellulase activity. Anal Biochem. 2:127-132.

Mussato, S.I., E.M.S. Machado, L.M. Carneiro, J.A. Teixeira. 2012. Sugar metabolism and ethanol production by different yeast strains from coffee industry wastes hydrolysates. Appl. Energy 92: 763-768.

Rao, R.S., B. Bhadra and S. Shivaji. 2008. Isolation and characterization of ethanolproducing yeasts from fruits and tree barks. Letters in Applied Microbiology. 47:19-24.

Singhania, R., Anil Kumar Patel, Rajeev K.Sukumaran, Christian Larroche, Ashok Pandey. 2013. Role and significance of beta-glucosidases in the hydrolysis of cellulose for bioethanol production. Bioresource Technology. 127: 500-507.

Srichuwong, S., M. Fujiwara, X. Wang, et al., 2009. Simultaneous saccharification and fermentation (SSF) of very high gravity (VHG) potato mash for the production of ethanol. Biomass- Bioenergy. 33: 890898.

Zahida Nasreen, Shaista Jabeen, Muafia Shafique, Shumaila Usman, Tehseen Yaseen, Ammara Yasmeen and Saima Nazir. 2014. Production of alcohol by yeast isolated from apple, orange and banana. International Journal of Food and Nutrition Sciences.1 (2): 016-019.

Zhao, J. and L. Xia. 2010. Bioconversion of corn stover hydrolysate to ethanol by a recombinant yeast strain. Fuel Process Technol. 91:1807-1811.

\section{How to cite this article:}

Geeta Shirnalli, Ashwini, M. and Dhanashree Gachhi. 2018. Isolation and Evaluation of Cellulolytic Yeasts for Production of Ethanol from Wheat Straw. Int.J.Curr.Microbiol.App.Sci. 7(12): 2215-2221. doi: https://doi.org/10.20546/ijcmas.2018.712.252 